\section{Een kind van zes}

In gedachten verzonken achter de computer hoor ik opeens sloffende voetstappen door de gang mijn kant op komen, vergezeld door bekende stemmen. De voetstappen horen bij Kevin. Hij komt bijna elke week met zijn begeleider Dusty. Kevin heeft veel nare dingen meegemaakt. Zijn moeder vindt haar eigen leven al erg ingewikkeld, laat staan het leven samen met haar zoon. Ze raakt geregeld de draad van haar bestaan kwijt en verliest Kevin dan uit het oog. Wie zijn vader is weet niemand. Kevin heeft op veel verschillende plekken gewoond met allerlei soorten mensen en meer dan tien scholen van binnen gezien. Het is hem niet gelukt om een diploma te halen. Hij is bijna verstrikt geraakt in de drugswereld en is diverse keren onder dwang opgenomen binnen de GGZ, omdat hij net als zijn moeder de grip op het leven dreigde te verliezen. $\mathrm{Na}$ de laatste opname is hij bij 's Heerenloo, de instelling waar ik sinds een poosje werk, komen wonen en gaat het wat beter met hem. Zijn hulpverleners merken dat Kevin last heeft van zijn verleden. Zij denken dat hij EMDR nodig heeft. Kevin denkt dat aanvankelijk zelf helemaal niet. Hij weet niet wat hem te wachten staat en is bang dat hij weer iets moet wat hij niet wil. Toch komt hij bij mij op bezoek. Zijn begeleider Dusty heeft hem gezegd dat een keertje kijken geen kwaad kan en dat Kevin daarna zelf bepaalt of hij het iets vindt.

De eerste keer was voor Kevin heel zwaar. Het zweet stond op zijn voorhoofd. We bekeken samen de kamer, probeerden de EMDRlamp uit, testen de 'bibberdingen' en luisterden naar 'de piepjes'. Kevin vertelde het eng te vinden om te komen, omdat hij mij niet kende en dus niet vertrouwde. Hij vertelde ook over zijn volle hoofd. Hij kon heel goed uitleggen dat zijn hoofd vaak te zwaar voor hem werd. Hij zou graag een manier leren om de nare

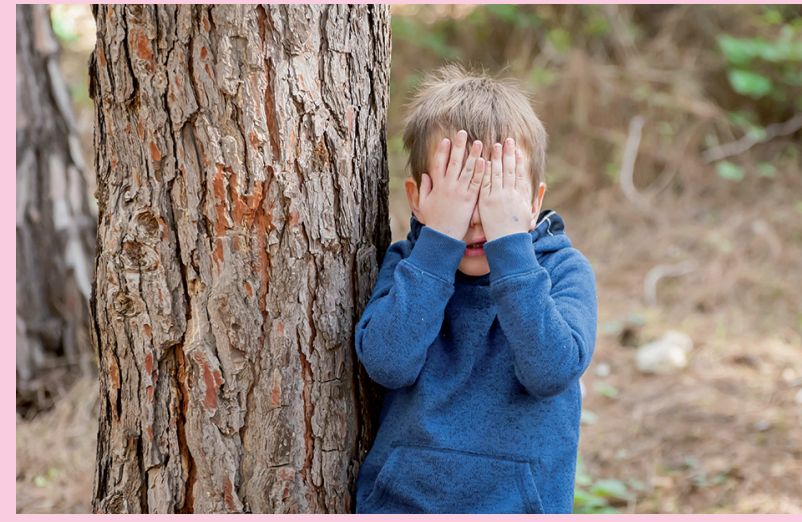

dingen uit zijn hoofd te laten verdwijnen. Als dat met EMDR kon, leek hem dat zeker iets. We spraken af de tijd te nemen om elkaar te leren kennen en om samen te kijken of er genoeg vertrouwen kwam om EMDR te gaan doen.

Natuurlijk kan ik u vertellen hoe het vertrouwen aan het groeien is en hoe hij na elke sessie thuis een tekening maakt over wat hij voelt, omdat hij verteld heeft dat hij soms overspoeld wordt door gevoelens als hij thuiskomt na therapie en niet weet wat hij daarmee moet. Hij tekent prachtige dingen en sluit steeds af met de zinnen 'Wat ik voel is goed. Ik heb hard gewerkt en dat is goed' - wat hem rust geeft. En hoe hij leert dat hij verschillende dingen kan voelen en dat we die gevoelens straks mooi kunnen gebruiken bij EMDR. Natuurlijk kan ik u dat vertellen, maar eigenlijk ook weer niet. Kevin is namelijk een man van 28 . Hij past dus niet bij de groep waarover dit tijdschrift gaat. Kevin weet zelf ook dat hij geen kind meer is. Hij zegt het treffend: "Ik ben een volwassen man van 28 jaar, maar in mij woont een kind van zes dat nooit ouder wordt."

$\mathrm{Na}$ de sessie hoor ik Kevins sloffende voetstappen door de gang steeds zachter worden. Bij 's Heerenloo werk ik een dag per week met volwassen cliënten. De rest gaat op aan regel-, denk-, en schrijfwerk. Natuurlijk ga ik weer kinderen zien, als de poli eenmaal draait. Ik weet alleen nog niet wanneer. Tot die tijd herinneren mensen als Kevin me eraan dat dat kind van zes, ergens diep van binnen, in ons allemaal huist. 